\title{
Potensi Bahaya Kontaminasi Logam Berat di Lahan Bekas Tambang Batubara yang Digunakan Sebagai Lahan Pertanian
}

\author{
Potential Dangers of Heavy Metal Contamination in the Coal Mine Used Land \\ as Agricultural Land
}

\author{
Haryatie Sarie* \\ Program Studi Pengelolaan Lingkungan, Politeknik Pertanian Negeri Samarinda, Indonesia. \\ *Correspondence Author: yatie787@gmail.com
}

\begin{abstract}
ABSTRAK
Tujuan penelitian ini adalah untuk mengetahui kontaminasi logam berat dengan menganalisis beberapa logam berat seperti logam $\mathrm{Pb}, \mathrm{Hg}, \mathrm{Cd}$ di dalam tanaman buah pisang dan buah pepaya di lahan bekas tambang batubara. Kandungan logam yang dianalisis akan dibandingkan dengan baku mutu kandungan logam berat tanaman menurut SNI 7387:2009. Data penelitian ini diambil pada tahun 2013. Lokasi yang diteliti adalah 2 lokasi bekas tambang batubara (2 lokasi lahan bekas tambang yang sudah ditanami pepaya dan pisang). Jumlah sampel tanaman ada 2 sampel (buah pisang dan buah pepaya. Kandungan logam berat dianalisis menggunakan alat Atomic Absorption Spectrofotometer (AAS). Hasil penelitian pada buah pisang dan pepaya menunjukkan pencemaran logam berat $\mathrm{Pb}$ karena melebihi bakumutu 0,5 mg/Kg untuk batas aman, sehingga berbahaya dikonsumsi manusia, kecuali logam Cd tidak terdeteksi, sedangkan logam $\mathrm{Hg}$ masih di level aman karena dibawah bakumutu $0.03 \mathrm{mg} / \mathrm{Kg}$.
\end{abstract}

Kata Kunci : Kontaminasi logam berat, lahan bekas tambang batubara, lahan pertanian

\section{ABSTRACT}

The purpose of this study was to determine heavy metal contamination by analyzing several heavy metals such as $\mathrm{Pb}, \mathrm{Hg}, \mathrm{Cd}$ metals in banana and papaya fruit plants in the former coal mining land. The metal content analyzed will be compared with the quality standard of plant heavy metal content according to SNI 7387: 2009. The data of this study were taken in 2013. The locations studied were 2 locations of the former coal mines (2 locations of ex-mining land that had been planted with papaya and bananas). The number of plant samples were 2 samples (bananas and papaya. Heavy metal content was analyzed using the Atomic Absorption Spectrophotometer (AAS). The results of studies on bananas and papayas showed pollution of heavy metals $\mathrm{Pb}$ because they exceeded the body temperature of $0.5 \mathrm{mg} / \mathrm{kg}$ for safe limits, so it is dangerous for human consumption, except the Cd metal is not detected, while the $\mathrm{Hg}$ metal is still at a safe level because it is below $0.03 \mathrm{mg} / \mathrm{kg}$.

Keywords: Heavy metal contamination, ex-coal mine land, agricultural land

\section{PENDAHULUAN}

Batubara merupakan salah satu jenis bahan tambang yang memiliki nilai ekonomis cukup tinggi. Indonesia adalah salah satu negara penghasil batubara terbesar no. 2 setelah Australia hingga tahun 2008. Total sumber daya batubara yang dimiliki Indonesia mencapai 104.940 Milyar Ton dengan total cadangan sebesar 21.13 Milyar Ton. Hal ini memberikan efek yang negatif maupun positif. Hal positifnya adalah bertambahnya devisa negara dari kegiatan penambanganya, sedangkan dampak negatifnya adalah kerusakan lingkungan dan masalah kesehatan yang ditimbulkan oleh proses penambangan. Kerusakan lingkungan akibat kegiatan penambangan juga akan meninggalkan lahan bekas penambangan dengan kondisi fisik tanah yang telah rusak, kesuburan tanah rendah, keasaman tanah tinggi, kandungan logam berat yang tinggi, serta bahan organik tanah yang rendah.Salah satu polutan yang sangat berbahaya bagi kesehatan manusia adalah logam berat WHO (World Health Organisation) dan FAO (Food Agriculture Organisation) merekomendasikan untuk tidak mengkonsumsi makanan laut (seafood) yang tercemar logam berat. Logam berat biasanya menimbulkan efek khusus pada makhluk hidup. Dapat dikatakan bahwa semua logam berat dapat menjadi racun bagi tubuh makhluk hidup apabila melampaui ambang 
batas yang diizinkan. Namun sebagian dari logam berat tersebut memang dibutuhkan oleh tubuh makhluk hidup dalam jumlah tertentu (sedikit), yang juga apabila tidak terpenuhi akan berakibat fatal terhadap kelangsungan hidup dari makhluk hidup tersebut (Kusnoto dan Kusumodirjo, 1995).

Batu bara adalah batuan hidrokarbon padat yang terbentuk dari berbagai tumbuhan dalam lingkungan bebas oksigen serta terkena pengaruh tekanan dan panas yang berlangsung sangat lama. Penambangan batubara selain memberikan kontribusi terhadap penyediaan sumber energi, penyerapan tenaga kerja dan pertumbuhan ekonomi, juga menimbulkan kerusakan kondisi lingkungan. Kerusakan tersebut perlu segera diperbaiki melalui usaha reklamasi lahan tambang untuk mengembalikan daya dukung tanah sehingga dapat menyediakan tanah yang produktif. Sistem penambangan batubara di Indonesia, pada umumnya adalah sistem tambang terbuka dengan metode konvensional. Urutan kegiatan penambangan terbuka meliputi : 1) pembukaan lahan; 2) pengupasan dan penimbunan tanah tertutup; 3) pengambilan dan pengangkatan batubara serta pengecilan ukuran. Kusnoto dan Kusumodirjo (1995) menyatakan bahwa salah satu limbah tambang adalah lapisan penutup yang digali dan dipindahkan pada kegiatan pertambangan. Dampak negatif terhadap lingkungan akibat kegiatan penambangan antara lain : 1) produktifitas tanah menurun; 2)pemadatan tanah; 3 ) terjadinya erosi dan sedimentasi; 4) terjadinya gerakan tanah dan longsoran; 5) terganggunya flora dan fauna; 6) terganggunya keamanan dan kesehatan penduduk; serta 7) perubahan iklim mikro. (Qomariah,2003).

Menurut Darmono (1995), logam berat termasuk dalam kelompok zat pencemar adalah karena adanya sifat-sifat logam berat yang tidak dapat terurai (non degradable) dan mudah diabsorbsi. Organisme pertama yang terpengaruh akibat penambahan polutan logam berat ke tanah atau habitat lainnya adalah organisme dan tanaman yang tumbuh ditanah atau habitat tersebut. Dalam ekosistem alam terdapat interaksi antar organisme baik interaksi positif maupun negatif yang menggambarkan bentuk transfer energi antar populasi dalam komunitas tersebut. Dengan demikian pengaruh logam berat tersebut pada akhirnya akan sampai pada hierarki rantai makanan tertinggi yaitu manusia.

Logam yang dapat menyebabkan keracunan adalah jenis logam saja. Logam ini termasuk logam yang essensial seperti $\mathrm{Cu}, \mathrm{Zn}$, Se dan yang nonesensial seperti $\mathrm{Pb}$, $\mathrm{Hg}, \mathrm{Cd}$, dan As.Terjadinya keracunan logam paling sering disebabkan pengaruh pencemaran lingkungan oleh logam berat, seperti penggunaan logam sebagai pembasmi hama (pestisida), pemupukan maupun karena pembuangan limbah pabrik yang menggunakan logam. Logam esensial seperti $\mathrm{Cu}$ dan $\mathrm{Zn}$ dalam dosis tertentu dibutuhkan sebagai unsur nutrisi pada hewan, tetapi logam nonesensial seperti $\mathrm{Hg}$, $\mathrm{Pb}, \mathrm{Cd}$, dan As sama sekali belum diketahui kegunaannya walaupun dalam jumlah relative sedikit dapat menyebabkan keracunan pada hewan. (Darmono,1995)

Berdasarkan latar belakang di atas maka pentingnya menganalisis kandungan logam berat dalam tanaman di lahan tambang batu bara untuk mencegah pencemaran lingkungan akibat logam berat dan dampak negatifnya terhadap makhluk hidup.Adapun tujuan penelitian ini adalah untuk menganalisis kandungan logam berat di dalam tanaman di lahan bekas tambang batu bara. Kandungan logam yang dianalisis akan dibandingkan dengan SNI baku mutu kandungan logam agar diketahui tingkat pencemarannya.

\section{METODE PENELITIAN}

\section{A. Tahapan Penelitian}

Tahapan penelitian identifikasi kontaminasi logam berat adalah dengan analisis logam berat tanaman pisang dan pepaya di Lahan Bekas Tambang Batu bara adalah :

1. Survey Lokasi untuk menentukan lahan yang akan disampling di lingkungan bekas tambang batu bara yang akan dianalisis logam beratnya (sampel secara komposit)

2. 2 tanaman (pepaya dan pisang) dan Menentukan 3 jenis logam berat yang akan dianalisis $(\mathrm{Hg},, \mathrm{Cd}, \mathrm{Pb})$

3. Mengambil 2 sampel komposit tiap petak tanaman (pepaya dan pisang) di 2 lahan bekas tambang batu bara yang diamati. 
4. Sampel Tanaman di analisis kadar logam beratnya di Laboratorium menggunakan spektrofotometer, kemudian hasil analisisnya dibandingkan dengan standar baku mutu lingkungan kandungan logam berat SNI 7387:2009 untuk mengetahui tingkat aman dan tidak aman jika dikonsumsi.

\section{B.Tempat Penelitian}

Tempat penelitian dilaksanakan di lahan perusahaan bekas tambang batubara Desa Embalut Kutai Kertanegara.

C. Metode Analisis Tanah dan tanaman

Analisis logam berat Tanah dan Tanaman menggunakan Metode Juknis Analisis Kimia Tanah Tanaman, Air dan Pupuk, BPT Deptan 2005, diukur menggunakan AAS.

\section{HASIL DAN PEMBAHASAN}

Berikut ini adalah data analisis logam berat $\mathrm{Pb}, \mathrm{Hg}, \mathrm{Cd}$ dalam tanaman pisang dan papaya di lahan bekas tambang batubara Desa Embalut Kutai kertanegara.

Tabel 1. Hasil Analisis 4 Logam Berat dalam Tanaman di Lahan Bekas Tambang Batubara

\begin{tabular}{lc}
\hline Tanaman & $\begin{array}{c}\text { Logam Berat } \\
(\mathrm{mg} / \mathrm{Kg})\end{array}$ \\
\hline Pisang & $\mathbf{P b}=67,0 ; \mathbf{C d}=\mathrm{ttd} ; \mathbf{H g}=0,007$ \\
Pepaya & $\mathbf{P b}=53,0 ; \mathbf{C d}=\mathrm{ttd} ; \mathbf{H g}=0,01$
\end{tabular}

Ket : $\mathrm{ttd}=$ tidak terdeteksi

Analisis sampel tanaman ini dilakukan di Laboratorium PT.Mutuagung Bogor dengan menggunakan alat AAS untuk mengetahui kandungan logam berat dan menggunakan metode Juknis Analisa Kimia Tanah Tanaman Air dan Pupuk BPT Deptan, 2005. Jenis sampel tanaman ini ada 2 jenis 1).Sampel buah pisang, 2).Sampel buah pepaya. Jenis logam yang diamati adalah logam raksa $(\mathrm{Hg})$, logam timbal $(\mathrm{Pb})$, logam cadmium (Cd). Kandungan 3 logam berat yang di analisis ( $\mathrm{Pb}, \mathrm{Hg}, \mathrm{Cd}$ ) ada 1 jenis logam yang tidak terdeteksi yaitu logam $\mathrm{Cd}$. Sedangkan 2 logam lainnya dapat terdeteksi yaitu logam $\mathrm{Hg}$ dan logam $\mathrm{Pb}$. Adapun kandungan logam berat dalam tanaman pisang dan pepaya adalah logam $\mathrm{Pb}$ untuk sampel buah pisang $=67,0 \mathrm{mg} / \mathrm{Kg}$, logam $\mathrm{Pb}$ untuk sampel buah papaya $=53,0 \mathrm{mg} / \mathrm{Kg}$.

Sesuai pengertian di atas maka data analisis logam berat perlu dilakukan perbandingan dengan bakumutu logam berat dalam pangan/tanaman serta jumlah yang aman untuk dikonsumsi manusia. Berikut ini adalah bakumutu logam berat yang aman/batas maksimum dalam pangan. (SNI 7387:2009).

Tabel 2. Baku mutu logam berat dalam Pangan berdasarkan SNI 7387:2009

\begin{tabular}{ccc}
\hline Logam & Pangan & Batas Maksimum \\
\hline $\mathrm{Cd}$ & Buah & $0.2 \mathrm{mg} / \mathrm{kg}$ \\
$\mathrm{Hg}$ & Buah & $0.03 \mathrm{mg} / \mathrm{Kg}$ \\
$\mathrm{Pb}$ & Buah & $0,5 \mathrm{mg} / \mathrm{Kg}$ \\
\hline
\end{tabular}

Perbandingan hasil analisis kandungan cemaran 3 logam berat yaitu logam $\mathrm{Cd}$, logam $\mathrm{Hg}$ dan logam $\mathrm{Pb}$ dengan bakumutu kandungan logam SNI dapat ditunjukan dalam grafik di bawah ini :

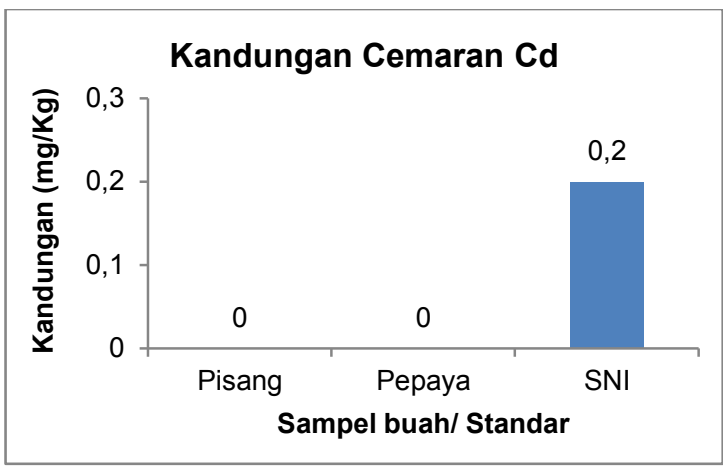

Gambar 1. Kandungan Cemaran Cd dalam Sampel Buah Pisang dan Pepaya yang

Ditanam di Areal Bekas Tambang Batubara

Pada Gambar 1 menunjukkan perbandingan kandungan cemaran logam $\mathrm{Cd}$ dalam sampel buah Pisang dan Pepaya yang ditanam di areal bekas Tambang Batubara, berdasarkan hasil analisis di Laboratorium Logam $\mathrm{Cd}$ pada buah pisang dan buah pepaya di areal bekas tambang batu bara tidak terdeteksi dan masih dalam batas aman kandungan logam $\mathrm{Cd}$ menurut SNI 7387:2009 adalah 0,2 mg/kg. 


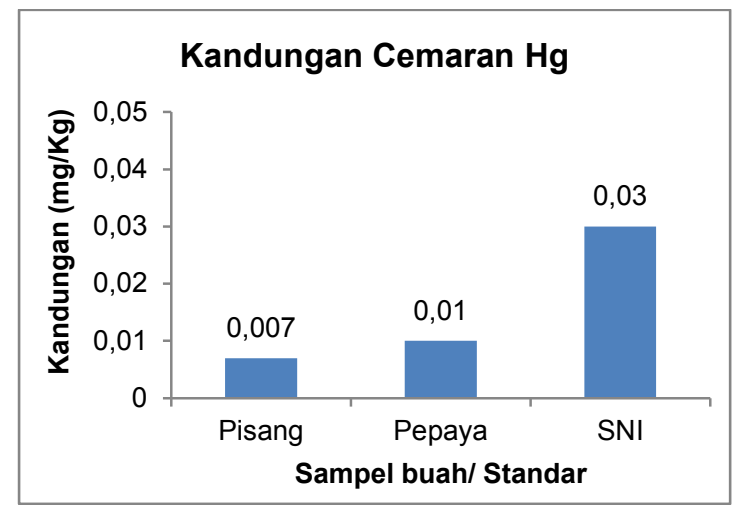

Gambar 2. Kandungan Cemaran $\mathrm{Hg}$ dalam Sampel Buah Pisang dan Pepaya yang Ditanam di Areal Bekas Tambang Batubara

Perbandingan kandungan cemaran logam $\mathrm{Hg}$ dalam sampel buah pisang dan pepaya di areal bekas tambang Batubara, berdasarkan hasil analisis di Laboratorium logam $\mathrm{Hg}$ terdeteksi dalam buah pisang sebesar $0.007 \mathrm{mg} / \mathrm{kg}$ dan buah pepaya sebesar $0.001 \mathrm{mg} / \mathrm{kg}$,

bila dibandingkan dengan SNI 7387:2009 batas aman logam $\mathrm{Hg}$ adalah 0,03 $\mathrm{mg} / \mathrm{kg}$ maka logam $\mathrm{Hg}$ dalam buah pisang dan buah pepaya masih dalam batas aman untuk dikomsumsi.

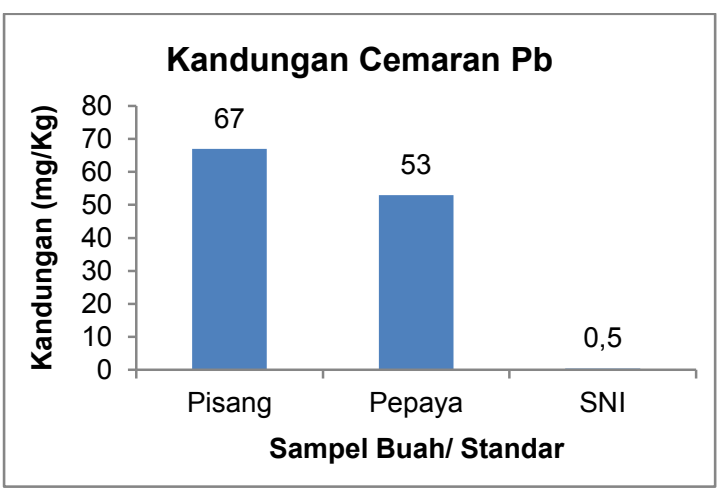

Gambar 3. Kandungan Cemaran Pb dalam Sampel Buah Pisang dan Pepaya yang

Ditanam di Areal Bekas Tambang Batubara

Pada Gambar 3 menunjukkan perbandingan kandungan cemaran logam $\mathrm{Pb}$ berdasarkan hasil analisis Laboratorium, kandungan logam $\mathrm{Pb}$ terdeteksi di atas batas aman SNI 7387:2009 yaitu 0,5 mg/kg, Sedangkan kandungan logam $\mathrm{Pb}$ dalam buah pisang adalah $67 \mathrm{mg} / \mathrm{kg}$ dan buah pepaya adalah $53 \mathrm{mg} / \mathrm{kg}$. Hal ini menunjukan adanya pencemaran logam berat $\mathrm{Pb}$ dan berbahaya bila di konsumsi oleh manusia. Dalam jangka lama $\mathrm{Pb}$ terakumulasi pada gigi, gusi dan tulang. Jika konsentrasi $\mathrm{Pb}$ meningkat, akan terjadianemia dan kerusakan fungsi otak serta kegagalan fungsi ginjal.Keracunan $\mathrm{Pb}$ pada orang dewasa ditandai dengan gejala seperti pucat, sakit dan kelumpuhan. Bila pada keracunan kronik, awalnya tidak menyebabkan gangguan kesehatan yang tampak, tetapi semakin lama efek toksik itu menumpuk hingga akhirnya terjadi gejala keracunan. Keracunan timbal kronik ditandai dengan depresi, sakit kepala, sulit berkonsentrasi, daya ingat terganggu dan sulit tidur. Sedangkan keracunan akut dapat terjadi bila timbal masuk kedalam tubuh seseorang lewat makanan atau menghirup uap timbal dalam waktu yang relatif pendek dengan dosis atau kadar yang relatif tinggi. Gejala yang timbul berupa mual, muntah, sakit perut hebat, kelainan fungsi otak, anemia berat, kerusakan ginjal, bahkan kematian. Pada perempuan yang sedang hamil, timbal yang tertimbun dalam tulang akan masuk ke janin dan asupan imbal dapat menyebabkan keguguran. Berdasarkan tabel bakumutu dan analisis buah papaya dan pisang di atas maka logam $\mathrm{Pb}$ yang kandungannya di atas bakumutu atau berada di taraf berbahaya untuk di konsumsi manusia dan kritis untuk kandungan dalam tanaman. Berdasarkan tabel 3 bakumutu logam berat dalam pangan dan tabel 2 analisis logam $\mathrm{Pb}, \mathrm{Hg}$, Cd pada buah papaya dan pisang di atas, maka logam $\mathrm{Pb}$ pada buah pisang dan pepaya yang kandungannya di atas bakumutu atau berada di level berbahaya untuk di konsumsi manusia dan kritis untuk kandungan dalam tanaman. Untuk logam Cd tidak terdeteksi dalam buah pisang dan pepaya, sedangkan logam $\mathrm{Hg}$ kandungannya masih di bawah bakumutu $0.03 \mathrm{mg} / \mathrm{kg}$ artinya masih dalam level aman.

\section{KESIMPULAN DAN SARAN}

Berdasarkan hasil analisis Laboratorium terhadap 3 logam berat $\mathrm{Pb}, \mathrm{Hg}$, Cd pada sampel komposit tanaman (buah pisang dan buah pepaya) maka logam yang membahayakan lingkungan adalah logam $\mathrm{Pb}$ karena jumlah kandungannya berada di atas baku mutu atau melampaui batas aman.

Lahan bekas tambang batubara harus dilakukan pengelolaan lingkungan (menghilangkan unsur berbahaya seperti 
logam berat) terlebih dahulu sebelum dilakukan penanaman khususnya tanaman buah-buahan karena berbahaya bila dikonsumsi manusia. Untuk mengetahui logam berat yang ada di lahan bekas tambang batubara perlu dilakukan analisis kandungan kimianya secara rutin dan dibutuhkan proses remediasi dengan metode ramah lingkungan untuk mengikat logam berat yang berbahaya. Dibutuhkan perencanaan evaluasi dan pengelolaan lahan yang komprehensif sebelum menggunakan lahan tambang batubara sebagai lahan pertanian.

\section{DAFTAR PUSTAKA}

Bapedal. 2001.Aspek Lingkungan Dalam Amdal bidang Pertambangan.Pusat Pengembangan dan Penerapan amdal.Jakarta

Darmono. 1995. Logam Dalam Sistem Biologi Makhluk Hidup. Jakarta: Universitas Indonesia (UI-Press)

Palar, H. 1994. Pencemaran \& Toksikologi Logam Berat. Jakarta: Rineka Cipta.

Rahayu, R.R.D. 2006. Penggunaan Sludge Industri Kertas untuk Meningkatkan Pertumbuhan Pulai pada Tanah Bekas Tambang Batubara. Skripsi. Program Studi Budidaya Hutan. Fakultas Kehutanan. Institut Pertanian Bogor, Bogor.

Saeni, M.S.1989. Kimia Lingkungan. Departemen Pendidikan dan Kebudayaan. Ditjen Pendidikan Tinggi.PAU.(Ilmu Hayati)IPB.Bogor.

Tala'oho et al. 1996. Reklamasi Tanah Timbunan Sisa Galian Penambangan Batu bara dan monitoring erosi di Tanjung Enim.Hal 41-59 dalam prosiding pertemuan pembahasan dan komunikasi hasil penelitian tanah dan agroklimat.Bidang fisika dan konservasi tanah dan air serta agroklimat dan hidrologi.Pusat penelitian tanah dan agroklimat departemen pertanian Bogor.

Supardi.2003.Lingkungan Hidup dan Kelestariannya.P.T Alumni.Bandung.

Qomariah, R. 2003. Dampak Kegiatan Pertambangan Tanpa ljin (PETI) Batubara terhadap Kualitas Sumberdaya Lahan dan Sosial Ekonomi Masyarakat di Kabupaten Banjar Kalimantan Selatan. Tesis. Program Pascasarjana, Institut Pertanian Bogor, Bogor.

Kusnoto dan Kusumodirdjo. 1995. Dampak Penambangan dan Reklamasi. Ditjen pertambangan Umum. Pusat Penelitian dan Pengembangan Teknologi Mineral, Bandung. 